\section{Optimal dose of thiamylal in combina- tion with midazolam for induction of anaesthesia}

Purpose: The optimal dose range of thiamylal, combined with midazolam, in the induction of anaesthesia was evaluated using haemodynamic variables.

Methods: The 200 patients, aged 30 to $70 \mathrm{yr}$, were randomly divided into five groups by midazolam dosage. Anaesthesia was induced with midazolam $0.05,0.075,0.10,0.15$, or 0.20 $\mathrm{mg} \cdot \mathrm{kg}^{-1}$. Two minutes later, $50 \mathrm{mg}$ thiamylal was administered followed by $25 \mathrm{mg}$ increments until verbal response and eyelash reflex disappeared and blood pressure decreased to a level less than that of preinduction. Tracheal intubation was performed with $0.15 \mathrm{mg} \cdot \mathrm{kg}^{-1}$ vecuronium. Blood pressure and heart rate were monitored during induction. Optimal induction was defined as a systolic blood pressure one minute after intubation within $\pm 20 \%$ of that before induction.

Results: There were 164 patients whose systolic blood pressure were within these criteria. Blood pressure decreased two minutes after induction and 3 to 15 min after intubation in all groups. Heart rate increased one minute after intubation in $0.05 \mathrm{mg} \cdot \mathrm{kg}^{-1}, 0.075 \mathrm{mg} \cdot \mathrm{kg}^{-1}$ and $0.10 \mathrm{mg} \cdot \mathrm{kg}^{-1}$ midazolam groups. The optimal range of thiamylal was $4.0 \pm 1.1$ (mean + $S D), 3.1 \pm 1.2,2.8 \pm 1.1,2.3 \pm 1.2$, and $1.7 \pm 1.0 \mathrm{mg} \cdot \mathrm{kg}^{-1}$ in combination with midazolam $0.05,0.075,0.10,0.15$, and 0.20 $\mathrm{mg} \cdot \mathrm{kg}^{-1}$, respectively.

Conclusion: The optimal dose range, to maintain haemodynamic stability, for thiamylal induction of anaesthesia in combination with midazolam, $0.05-0.2 \mathrm{mg} \cdot \mathrm{kg}^{-1}$ was found to range from 4.0 to $1.7 \mathrm{mg} \cdot \mathrm{kg}^{-l}$.

Objectif: Rechercher l'éventail posologique optimal du thyamilal adminstré en association au midazolam pour induire l'anesthésie en tenant compte des variables hémodynamiques.

\section{Key words}

ANAESTHESIA: induction;

ANAESTHETICS, INTRAVENOUS: midazolam, thiamylal.

From the Department of Anesthesiology, Faculty of Medicine, The University of Tokyo 7-3-1, Hongo, Bunkyo-ku, Tokyo, 113 Japan.

Address correspondence to: Dr. Tomoki Nishiyama, 8042

Regents Road, \#203, San Diego, CA 92122, USA.

Accepted for publication 20th June, 1996.
Méthodes: Deux cents patients agés de 30 à 70 ans, ont été répartis aléatoirement entre cinq groupes selon la dose du midazolam. L'anesthésie était induite avec du midazolam 0,05 , $0,075,0,10,0,15$, ou $0,20 \mathrm{mg} \cdot \mathrm{kg}^{-1}$. Deux minutes plus tard, on administrait du thyamilal $50 \mathrm{mg}$ suivi par des doses addition. nelles de $25 \mathrm{mg}$ jusqu'à la perte de la réponse verbale et du réflexe ciliaire et jusqu'à ce que la pression baisse à un niveau inférieur à celui précédent l'induction. La trachée a été intubée avec du vécuronium $0,15 \mathrm{mg} \cdot \mathrm{kg}^{-1}$. La pression sanguine et la fréquence cardiaque étaient monitorisées pendant l'induction. L'induction était considérée comme optimale si, une minute après l'intubation, la pression artérielle systolique ne variait que de $\pm 20 \%$ de la pression pré-induction.

Résultats: La pression systolique de 164 patients s'est maintenue à l'intérieur de ces limites. La pression artérielle a diminué deux minutes après l'induction et de 3 à 15 minutes après l'intubation dans tous les groupes. La fréquence cardiaque a augmenté une minute après l'intubation chez les groupes midazolam $0,05 \mathrm{mg} \cdot \mathrm{kg}^{-1}, 0,075 \mathrm{mg} \cdot \mathrm{kg}^{-1}$ et 0,10 $m g \cdot \mathrm{kg}^{-1}$. L'éventail optimal du thyamilal était respectivement 4,01 $\pm 1,1$ (moyenne $\pm E T$ ), 3,1 $\pm 1,2,2,8 \pm 1,1,2,3 \pm 1,2$ et $1,7 \pm 1,0 \mathrm{mg} \cdot \mathrm{kg}^{-1}$ en association avec $0,05,0,075,0,10,0,15$ et $0,20 \mathrm{mg} \cdot \mathrm{kg}^{-1}$.

Conclusion: L'éventail posologique optimal pour maintenir une stabilité hémodynamique pour induire l'anesthésie au thyamilal associé au midazolam $0,05-0,2 \mathrm{mg} \cdot \mathrm{kg}^{-1}$ se situait entre 4,0 et $1,7 \mathrm{mg} \cdot \mathrm{kg}^{-1}$.

Midazolam is used in the induction of anaesthesia because of its short duration, amnesic action, and minimal pain on injection, even though the onset is slower than that of the barbiturates.

Conversely, barbiturates are ultrashort acting, but usually produce a marked, dose dependent, haemodynamic effect and may cause pain on injection. In our efforts to decrease the dose and ameliorate the disadvantages of each of these drugs, we previously studied an induction method with combination of midazolam and barbiturates. 1,2

In one study, we found that combined induction using $0.2 \mathrm{mg} \cdot \mathrm{kg}^{-1}$ midazolam and $1.9 \mathrm{mg} \cdot \mathrm{kg}^{-1}$ thiamylal was 
TABLE I Demographic data

\begin{tabular}{|c|c|c|c|c|c|}
\hline & $\begin{array}{l}\text { Group A } \\
0.05 \mathrm{mg} \cdot \mathrm{kg}^{-1}\end{array}$ & $\begin{array}{l}\text { Group B } \\
0.075 \mathrm{mg} \cdot \mathrm{kg}^{-1}\end{array}$ & $\begin{array}{l}\text { Group C } \\
0.10 \mathrm{mg} \cdot \mathrm{kg}^{-1}\end{array}$ & $\begin{array}{l}\text { Group D } \\
0.15 \mathrm{mg} \cdot \mathrm{kg}^{-1}\end{array}$ & $\begin{array}{l}\text { Group E } \\
0.20 \mathrm{mg} \cdot \mathrm{kg}^{-1}\end{array}$ \\
\hline$n$ & 34 & 34 & 32 & 30 & 34 \\
\hline $\mathrm{M} / \mathrm{F}$ & $16 / 18$ & $10 / 24$ & $10 / 22$ & $18 / 12$ & $22 / 12$ \\
\hline Age (yr) & $49 \pm 14$ & $51 \pm 13$ & $54 \pm 12$ & $55 \pm 121$ & $53 \pm 11$ \\
\hline Weight (kg) & $54.2 \pm 7.0$ & $52.3 \pm 8.1$ & $52.5 \pm 9.2$ & $54.3 \pm 3.4$ & $53.5 \pm 9.3$ \\
\hline Surgery (min) & $180 \pm 52$ & $177 \pm 83$ & $210 \pm 100$ & $208 \pm 80$ & $188 \pm 55$ \\
\hline Anaesthesia (min) & $250 \pm 55$ & $239 \pm 85$ & $276 \pm 120$ & $285 \pm 90$ & $277 \pm 71$ \\
\hline Intubation time (min) & $5.2 \pm 1.5$ & $5.6 \pm 2.5$ & $5.1 \pm 1.5$ & $5.2 \pm 1.0$ & $5.5 \pm 1.3$ \\
\hline Extubation time (min) & $12.5 \pm 5.5$ & $13.0 \pm 6.1$ & $13.0 \pm 4.1$ & $15.3 \pm 8.0$ & $12.6 \pm 4.3$ \\
\hline Midazolam (mg) & $2.8 \pm 0.3^{*}$ & $3.8 \pm 0.7^{*}$ & $5.3 \pm 0.9^{*}$ & $8.1 \pm 0.6^{*}$ & $10.6 \pm 1.6^{*}$ \\
\hline
\end{tabular}

Mean \pm SD.

* $P<0.05$ vs other four groups.

Intubation time was the time from the start of midazolam injection to intubation, and extubation time was the time from the end of nitrous oxide inhalation to extubation.

superior to the commonly used $4-5 \mathrm{mg} \cdot \mathrm{kg}^{-1}$ thiamylal with regard to circulatory response and local irritation. ${ }^{2}$ However, no detailed study has been performed to ascertain the optimal dose of these drugs when used in combination. The present study was initiated to determine the optimal dose of barbiturate in combination with various doses of midazolam for the induction of anaesthesia in adults.

\section{Methods}

After institutional approval and written informed consent were obtained, we evaluated 200 ASA I or II patients, aged 30 to $70 \mathrm{yr}$, scheduled to undergo elective surgery. We excluded patients who had taken any drug before surgery except for preanaesthetic medication, those scheduled for neuro- or cardiovascular surgery and those in whom difficult intubation was anticipated. Patients were randomly divided into five groups of 40 patients each according to the dose of midazolam administered: Group A received $0.05 \mathrm{mg} \cdot \mathrm{kg}^{-1}$, Group B $0.075 \mathrm{mg} \cdot \mathrm{kg}^{-1}$, Group C $0.10 \mathrm{mg} \cdot \mathrm{kg}^{-1}$, Group D 0.15 $\mathrm{mg} \cdot \mathrm{kg}^{-1}$, and Group E $0.20 \mathrm{mg} \cdot \mathrm{kg}^{-1}$.

Each patient received $0.5 \mathrm{mg}$ atropine and $50 \mathrm{mg}$ hydroxyzine im as preanaesthetic medication $30 \mathrm{~min}$ before the start of anaesthesia.

Blood pressure (measured by auscultation) and heart rate (measured by ECG) were monitored from before induction to $15 \mathrm{~min}$ after the intubation.

Anaesthesia was induced with each dose of midazolam. Then $1 \mathrm{mg}$ vecuronium was administered. Two minutes after administration of midazolam, verbal response and eyelash reflex were examined when $50 \mathrm{mg}$ thiamylal had been administered. Thiamylal was then given in $25 \mathrm{mg}$ increments every $30 \mathrm{sec}$ until verbal response and eyelash reflex disappeared and blood pressure decreased to a level less than that before induction. Tracheal intubation was facilitated with $0.15 \mathrm{mg} \cdot \mathrm{kg}^{-1}$ vecuronium and intratracheal injection of $2 \mathrm{ml}$ lidocaine $4 \%$ and was performed when the the train-of-four response using a muscle relaxant monitor had disappeared. For the $15 \mathrm{~min}$ after intubation, anaesthesia was maintained with $3 \mathrm{~L} \cdot \mathrm{min}^{-1} 1$ nitrous oxide in $2 \mathrm{~L} \cdot \mathrm{min}^{-1}$ oxygen in the absence of surgical stimulation. Thereafter, anaesthesia was maintained with sevoflurane 0.5 to $2.0 \%$ and $3 \mathrm{~L} \cdot \mathrm{min}^{-1}$ nitrous oxide in $2 \mathrm{~L} \cdot \mathrm{min}^{-1}$ oxygen.

Intubation time was defined as the time between midazolam administration and intubation. Extubation time was determined as the time from the end of nitrous oxide inhalation and extubation. ${ }^{2}$

Optimal anaesthesia induction was defined as a systolic blood pressure one minute after intubation within $20 \%$ of the preinduction value. The optimal dose range of thiamylal was defined as a mean \pm SD that produced optimal induction condition.

All data are given as the mean \pm SD. Statistical analysis was performed by chi-square analysis for the number of patients and sex and by analysis of variance (ANOVA) followed by Fisher's PLSD for all other variables in demographic data. ANOVA with repeated measures followed by Fisher's PLSD was used for blood pressure and heart rate. A $P$ value $<0.05$ was considered statistically significant.

\section{Results}

Optimal induction conditions were achieved in 164 patients. In the other 36, the systolic blood pressure was $>120 \%$ of the preinduction value. No differences were noted between the five groups with regard to the patients, group characteristics (Table I).

Group E $\left(0.2 \mathrm{mg} \cdot \mathrm{kg}^{-1}\right.$ midazolam $)$ had a larger number of patients than Group A $\left(0.05 \mathrm{mg} \cdot \mathrm{kg}^{-1}\right)$ whose verbal response and eyelash reflex disappeared two minutes after midazolam administration (Table II).

Blood pressure decreased two minutes after induc- 
TABLE II Verbal response and eyelash reflex at two minutes

\begin{tabular}{llllll}
\hline & Group $A$ & Group B & Group C & Group D & Group E \\
\hline Loss of verbal response, $n$ & 18 & 22 & 24 & 24 & $34^{*}$ \\
Loss of eyelash reflex, $n$ & 16 & 24 & 26 & 24 & $30^{*}$ \\
\hline
\end{tabular}

Mean \pm SD.

$* P<0.05$ vs Group A.

Verbal response and eyelash reflex were examined two minutes after midazolam administration.

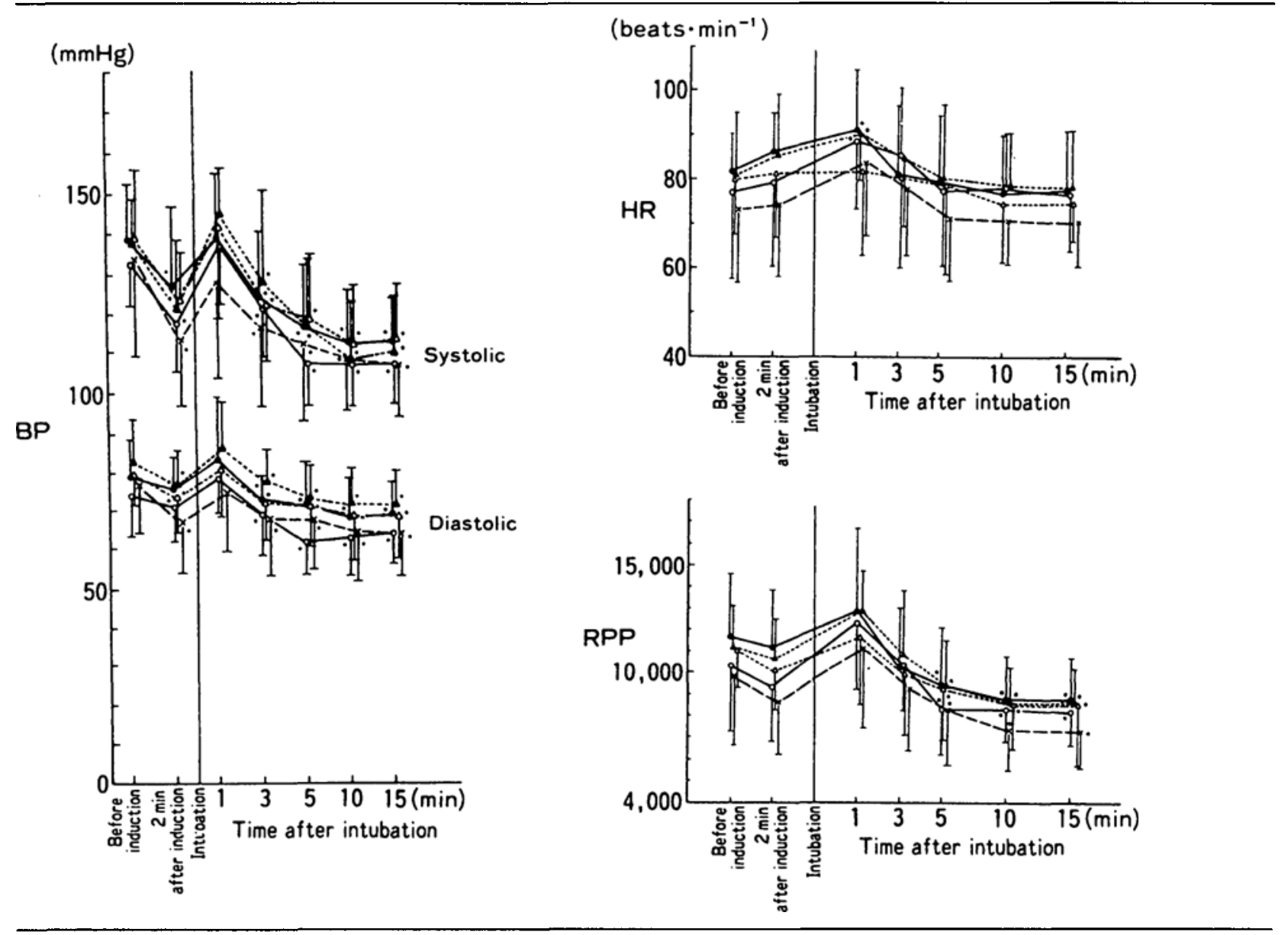

FIGURE 1 Blood pressure and heart rate BP: blood pressure; HR: heart rate Closed circles indicate Group A (midazolam $0.05 \mathrm{mg} \cdot \mathrm{kg}^{-1}$ ), open circles Group B $\left(0.075 \mathrm{mg} \cdot \mathrm{kg}^{-1}\right)$, closed triangles Group C $\left(0.10 \mathrm{mg} \cdot \mathrm{kg}^{-1}\right)$, open triangles Group $\left(0.15 \mathrm{mg} \cdot \mathrm{kg}^{-1}\right)$, and crosses Group $\mathrm{E}(0.20$ $\left.\mathrm{mg} \cdot \mathrm{kg}^{-1}\right)$. Bars show the standard deviation. ${ }^{*} P<0.05$ vs value before induction.

tion and 3 to $15 \mathrm{~min}$ after the intubation in all groups. Heart rate increased one minute after intubation in Groups A $\left(0.05 \mathrm{mg} \cdot \mathrm{kg}^{-1}\right), \mathrm{B}\left(0.075 \mathrm{mg} \cdot \mathrm{kg}^{-1}\right)$ and C $\left(0.10 \mathrm{mg} \cdot \mathrm{kg}^{-1}\right)$. There were no differences among the five groups in blood pressure or heart rate during the study (Figure 1).

No patient complained of pain on injection of midazolam or thiamylal or developed any arrhythmia during the study.

The optimal dose of thiamylal was found to be $225 \pm$ $74 \mathrm{mg}\left(4.0 \pm 1.1 \mathrm{mg} \cdot \mathrm{kg}^{-1}\right)$ in Group A, $153 \pm 60 \mathrm{mg}$ $\left(3.1 \pm 1.2 \mathrm{mg} \cdot \mathrm{kg}^{-1}\right)$ in Group B, $147 \pm 66 \mathrm{mg}(2.8 \pm 1.1$ $\left.\mathrm{mg} \cdot \mathrm{kg}^{-1}\right)$ in Group C, $125 \pm 75 \mathrm{mg}\left(2.3+1.2 \mathrm{mg} \cdot \mathrm{kg}^{-1}\right)$ in Group $\mathrm{D}$, and $91 \pm 32 \mathrm{mg}\left(1.7 \pm 1.0 \mathrm{mg} \cdot \mathrm{kg}^{-1}\right)$ in Group E. Patients in group A (midazolam 0.05 $\mathrm{mg} \cdot \mathrm{kg}^{-1}$ ) required a larger dose than did patients in the other groups and Group $\mathrm{E}\left(0.20 \mathrm{mg} \cdot \mathrm{kg}^{-1}\right)$ needed a smaller dose than did Groups B and C. The optimal range is expressed in Figure 2.

\section{Discussion}

In our previous report, using a combination of midazo- 


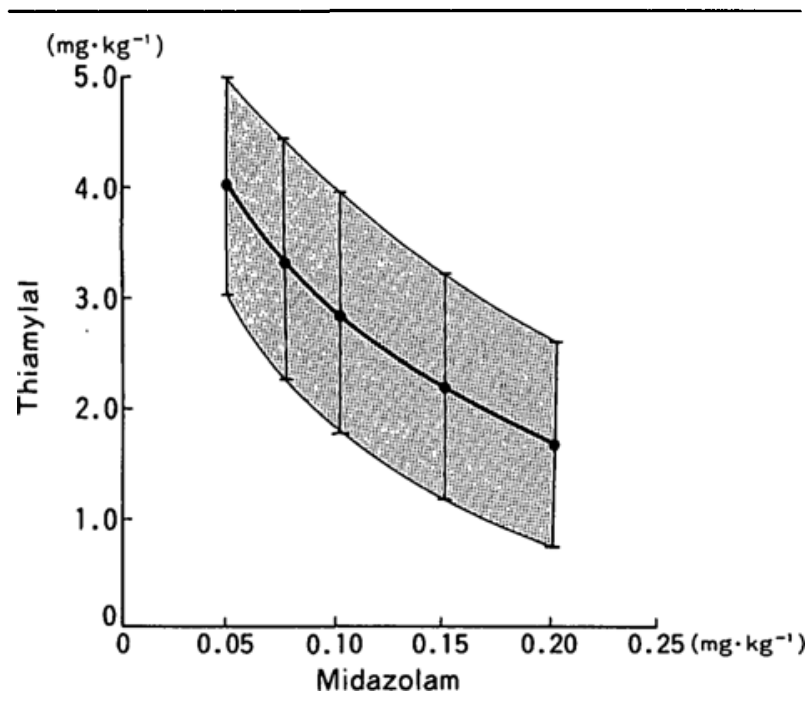

FIGURE 2 Optimal dose range. Bars = SD. Shaded area indicates optimal range.

lam $0.2 \mathrm{mg} \cdot \mathrm{kg}^{-1}$ and thiamylal $1.9 \mathrm{mg} \cdot \mathrm{kg}^{-1}$, recovery from anaesthesia was delayed compared with induction with thiamylal alone. ${ }^{2}$ This delay was due to the effect of midazolam. Thus, in the present study, we evaluated induction using midazolam doses $<0.2 \mathrm{mg} \cdot \mathrm{kg}^{-1}$. Since this study included surgery of about three hours durations, there were no differences in extubation time among the five groups. The extubation times in the present study might have been longer than that of induction with thiamylal alone in our previous study. ${ }^{2}$ Further evaluation during shorter-duration surgery is essential to add a time scale range to our study.

The most useful combination dose in our previous report was $0.2 \mathrm{mg} \cdot \mathrm{kg}^{-1}$ midazolam and $1.9 \mathrm{mg} \cdot \mathrm{kg}^{-1}$ thiamylal, ${ }^{2}$ which was also within the optimal dose range in the present study.

As indices of hypnotic or anaesthetic effects, we used verbal response, eyelash reflex and blood pressure, which are easily monitored during clinical anaesthesia. However, about $80 \%$ of the subjects were enrolled in the optimally induced patients in the present study, indicating that these variables were sufficient for evaluating the hypnotic or anaesthetic effects in clinical anaesthesia.

The hypnotic or anaesthetic action of both midazolam and barbiturates is mediated by the $\gamma$-aminobutyric acid $(\mathrm{GABA})_{\mathrm{A}}$ receptor in brain. ${ }^{3}$ The interaction of barbiturates and midazolam is synergistic on the righting reflex in rats $^{4}$ and on the response to verbal command ${ }^{5}$ and electrical stimulation ${ }^{6}$ in man. These experimental findings suggest that the mechanism of the synergism is that barbiturates enhance the binding of benzodiazepines to benzodiazepine receptors, augmenting binding of
GABA to $\mathrm{GABA}_{\mathrm{A}}$ receptors, and intensifying the coupling between $\mathrm{GABA}_{\mathrm{A}}$ receptor activation and chloride channel opening. ${ }^{7,9}$ This synergism was not substantiated in the present study because our focus was not in examining the synergism but rather in investigating the optimal dose ranges of the drugs. Regardless of whether the combination of midazolam and thiamylal generates a synergistic action, the small haemodynamic changes witnessed suggest that this combination constitutes a useful and safe method of inducing anaesthesia.

In conclusion, we determined the optimal dose range of thiamylal used in anaesthesia induction in combination with 0.05 to $2.0 \mathrm{mg} \cdot \mathrm{kg}^{-1}$ midazolam in a series of 30- to 70-yr-old patients. The optimal doses of thiamylal combined with $0.05,0.075,0.10,0.15$, or $0.20 \mathrm{mg} \cdot \mathrm{kg}^{-1}$ midazolam were found to be $225+74 \mathrm{mg}(4.0 \pm 1.1$ $\left.\mathrm{mg} \cdot \mathrm{kg}^{-1}\right), 153 \pm 60 \mathrm{mg}\left(3.1 \pm 1.2 \mathrm{mg} \cdot \mathrm{kg}^{-1}\right), 147+66$ $\mathrm{mg}\left(2.8 \pm 1.1 \mathrm{mg} \cdot \mathrm{kg}^{-1}\right), 125+75 \mathrm{mg}(2.3 \pm 1.2$ $\left.\mathrm{mg} \cdot \mathrm{kg}^{-1}\right)$, and $91 \pm 32 \mathrm{mg}\left(1.7 \pm 1.0 \mathrm{mg} \cdot \mathrm{kg}^{-1}\right)$, respectively.

\section{References}

1 Hanaoka K, Namiki A, Koga Y, Dohi S, Yuge O, Nishiyama T. Clinical evaluation of midazolam with combined use of barbiturate for the induction of anesthesia. (Japanese) J Jpn Soc Clin Anesth 1993; 13: 147-52.

2 Nishiyama T, Hirasaki A, Odaka Y, Ishii S, Ono T, Seto K. Induction of anesthesia with midazolam and thiamylal. (Japanese) Jpn J Anesthesiol 1994; 43: 818-22.

3 Delorey TM, Kissin I, Brown P, Brown GB. Barbituratebenzodiazepine interactions at the $\gamma$-aminobutyric acidA receptor in rat cerebral cortical synaptoneurosomes.

Anesth Analg 1993; 77: 598-605.

4 Kissin I, Mason JO III, Bradley EL Jr. Pentobarbital and thiopental anesthetic interactions with midazolam. Anesthesiology 1987; 67: 26-31.

5 Short TG, Galletly DC, Plummer JL. Hypnotic and anaesthetic action of thiopentone and midazolam alone and in combination. Br J Anaesth 1991; 66: 13-9.

6 Tverskoy M, Fleyshman G, Bradley EL Jr, Kissin I. Midazolam-thiopental anesthetic interaction in patients. Anesth Analg 1988; 67: 342-5.

7 Skolnick P, Moncada V, Barker JL, Paul SM. Pentobarbital: dual actions to increase brain benzodiazepine receptor affinity. Science 1981; 211: 1448-50.

8 Asano $T$, Ogasawara $N$. Chloride-dependent stimulation of GABA and benzodiazepine receptor binding by pentobarbital. Brain Res 1981; 225: 212-6.

9 Haefely $W$, Polc $P$. Physiology of GABA enhancement by benzodiazepines and barbiturates. In: Olsen RW, Venter JC (Eds.). Benzodiazepine/GABA Receptors and Chloride Channels. Structural and Functional Properties. New York: Alan R Liss, Inc., 1986: 97-133. 